\title{
Analisa Dampak Rasio Modal Saham Terhadap Pengambalian Investasi Pada Perubahan Subsektor Rokok Periode 2015
}

\author{
Titin Kartini \\ Fakultas Ilmu Administrasi Universitas Subang \\ titin.unsub@gmail.com
}

\begin{abstract}
Abstrak
Tujuan dilakukannya penelitian ini adalah untuk mengetahui pengaruh rasio modal saham terhadap return saham. Variabel yang digunakan meliputi ROE, PER, PTBV untuk mengukur rasio modal saham sementara return saham digunakan untuk mengukur kinerja perusahaan. Populasi pada subsektor rokok terdapat 4 perusahaan dengan menggunakan purposive sampling terdapat 2 perusahaan yang dijadikan sampel. Berdasarkan hasil penelitian dan analisis regresi berganda yang telah dilakukan, dapat diketahui bahwa variabel yang mewakili rasio modal saham yang meliputi ROE, PER, dan PTBV tidak berbengaruh terhadap return saham baik secara individu maupun bersama.
\end{abstract}

Kata Kunci : ROE, PER, PTBV dan Harga Saham.

\section{Abstract}

The purpose of this study is to determine the effect of the ratio of stock capital to stock returns. The variables used include ROE, PER, PTBV to measure the share capital ratio while stock returns are used to measure company performance. The population in the cigarette subsector there are 4 companies using purposive sampling there are 2 companies that are sampled. Based on the results of research and multiple regression analysis that has been done, it can be seen that the variables that represent the capital stock ratio which includes ROE, PER, and PTBV have no effect on stock returns both individually and together.

Keywords: ROE, PER, PTBV dan Return Saham.

\section{Pendahuluan}

Semakin membaiknya kondisi pasar modal Indonesia, akan semakin banyak menarik minat para investor untuk menanamkan uangnya pada pasar modal Indonesia. Meningkatnya kepercayaan para investor tentu akan meningkatkan pula 
geliat perekonomian di tanah air, dengan semakin banyaknya uang yang beredar dipasar modal tentu akan berdampak terhadap perekonomian negara secara garis besar. Dukungan pemerintah mutlak diperlukan untuk tetap mempertahankan kondisi ekonomi tersebut bahkan jika memungkinkan untuk meningkatkan menjadi lebih baik lagi. Meskipun pemerintah dalam mengeluarkan kebijakan tentunya memperhatikan kepentingan orang banyak, dalam hal ini masyarakat tetapi kebijakan tersebut tentu untuk kebaikan mereka juga, seperti kebijakan pemerintah mengenai rokok dalam hal ini menaikkan pita cukai rokok. Disatu sisi tidak dapat dipungkiri bahwa pemasukan pemerintah dari pajak pita rokok cukup besar tetapi diikuti pula dengan banyaknya usia muda masyarakat yang mengkonsumsi rokok, sehingga hal tersebut salah satu sebab pemerintah mengeluarkan kebijakan tersebut.

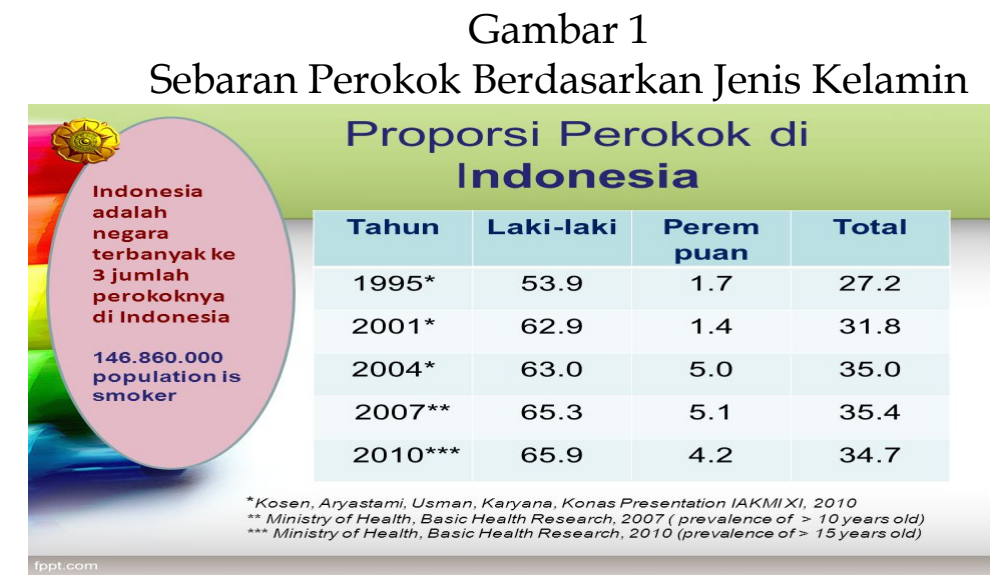

Terlepas dari pro dan kontra akan hal tersebut, bagi para investor sektor rokok merupakan salah satu sektor yang menarik minat, karena tingkat konsumsi rokok yang cenderung meningkat setiap tahun, bahkan seperti yang disampikan oleh Dirjen Bea dan Cukai berdasarkan capaian kinerja tahun 2015 didapatkan penerimaan negara dari cukai sebesar Rp. 144,6 triliun dengan target awal sebesar Rp. 195 triliun, dimana penerimaan tersebut disumbangkan oleh penerimaan cukai rokok sebesar 96,4\% atau sebesar Rp. 139,5 triliun. Selain itu, hasil yang didapatkan melalui pajak dalam rangka impor (PDRI) dan PPN hasil tembakau sebesar 193,6 triliun. Penerimaan yang didapatkan oleh lembaga tersebut setiap tahun mengalami peningkatan sebesar 8,35 berdasarkan perhitungan lima tahun terakhir. Dengan potensi yang besar dan hanya sedikit perusahaan yang tergabung hanya 4 perusahaan seperti yang tercatat pada sahamok yang diperbaharui 12 Agustus 2016 meliputi Gudang Garam Tbk, Handjaya Mandala Sampoerna Tbk, Bentoel International Investama Tbk dan Wismilak Inti Makmur Tbk semakin menarik minat para investor. Oleh karena itu, perusahaan dituntut untuk dapat membuat investor percaya bahwa dananya akan lebih produktif dan menguntungkan apabila para investor menyerahkan dananya kepada perusahaan. Dalam hal ini, pihak manajemen harus berupaya keras meningkatkan pencapaian dan kinerja perusahaan. Termasuk dalam lingkup tanggung jawab tersebut, manajemen harus dapat membuat kinerja keuangan yang sehat sehingga dapat memberikan jaminan pencapaian kepentingan semua pihak, baik internal maupun eksternal. Dengan demikian akan semakin banyak investor maka semakin meningkat pula modal 
saham perusahaan tersebut. Adapun tujuan dari penelitian ini adalah untuk mengetahui kinerja manajemen perusahaan yang tergabung dalam subsektor rokok dengan menggunakan analisis rasio modal saham. Dimana rasio modal saham diukur melalui rasio laba atas ekuitas (ROE), rasio harga-laba (PER) dan harga saham per nilai buku (PTBV).

\section{Kerangka Teori}

\section{a. Rasio Laba atas Ekuitas}

Rasio ini menggambarkan seberapa besar pendapatan yang diperoleh oleh seorang investor atas investasi yang dilakukannya pada perusahaan. Gill (2004). Dimana formulasi yang digunakan untuk menghitung rasio ini adalah sebagai berikut:

$$
R O E=\frac{\text { Pendapatan Setelah Pajak }}{\text { Modal Pemegang Saham }}
$$

Rasio ini menjelaskan seberapa besar para investor rela untuk membayar harga saham perusahaan untuk mendapatkan laba perusahaan sesuai dengan pelaporan yang dilakukan oleh perusahaan. Gill (2004). Formulasi yang digunakan untuk menghitung rasio ini adalah sebagai berikut:

$$
P E R=\frac{\text { Harga Pasar Per Lembar Saham }}{\text { Pendapatan Per lembar saham }}
$$

Rasio ini mengukur apakah harga pasar saham yang diperdagangkan berada diatas atau dibawah nilai buku saham itu sendiri. Hartono (2000). Formulasi yang digunakan untuk mengukur rasio tersebut adalah sebagai berikut:

$$
\text { PTBV }=\frac{\text { Harga Pasar Per Lembar Saham }}{\text { Nilai Buku Per Lembar saham }}
$$

Perumusan hipotesis dalam penelitian ini adalah sebagai berikut:

$\mathrm{H}_{\mathrm{o} 1}=0$ ROE tidak berpengaruh terhadap return saham

$\mathrm{H}_{\mathrm{a} 1} \neq 0$ ROE berpengaruh terhadap return saham

$\mathrm{H}_{\mathrm{o} 2}=0$ PER tidak berpengaruh terhadap return saham

$\mathrm{H}_{\mathrm{a} 2} \neq 0$ PER berpengaruh terhadap return saham

$\mathrm{H}_{\mathrm{o} 3}=0$ PTBV tidak berpengaruh terhadap return saham

$\mathrm{H}_{\mathrm{a} 3} \neq 0$ PTBV berpengaruh terhadap return saham

$\mathrm{H}_{\mathrm{o} 4}=0$ ROE, PER dan PTBV tidak berpengaruh terhadap return saham

$\mathrm{H}_{\mathrm{a} 4} \neq 0$ ROE, PER dan PTBV berpengaruh terhadap return saham

Penelitian ini termasuk pada penelitian kausal-asimetris, hal ini disebabkan tujuan penelitian itu sendiri untuk memperjelas hubungan kausal antara variabel melalui pengujian hipotesis. Dalam penelitian ini, populasi pada subsektor rokok terdapat 4 perusahaan dengan penarikan sampel berdasarkan purposive sampling sehingga didapatkan 2 perusahaan yang dijadikan sampel dengan kelengkapan data sesuai dengan periode penelitian, hubungan antara variabel yang digunakan adalah hubungan asimetris di mana hubungan terjadi ketika variabel independen mempengaruhi variabel dependen. 


\section{Metode Penelitian}

Dalam penelitian yang dilakukan, metodelogi yang digunakan adalah Regresi Linier Berganda. Metode ini digunakan untuk mengukur kekuatan hubungan antara variabel, menunjukkan seberapa besar pengaruh dan bagaimana arah hubungan antara variabel dependen (return saham) dengan variabel independen (ROE, PER dan PTBV). Data diolah dengan menggunakan perangkat lunak SPSS 20. Secara umum, rumus Analisis Regresi Linear Berganda adalah sebagai berikut:

$$
Y=a+\beta_{1} x_{1}+\beta_{2} x_{2}+\beta_{3} x_{3}+e
$$

$\mathrm{Y}=$ Return Saham

$\mathrm{a}=$ constanta

$1,2 \& \quad 3=$ regression coefficient $X_{1}, X_{2} \& X_{3}$

$\mathrm{X}_{1}=\mathrm{ROE}$

$X_{2}=$ PER

$\mathrm{X}_{3}=\mathrm{PTBV}$

$\mathrm{e}=$ error

Pengujian hipotesis dalam penelitian ini meliputi:

1. Uji Koefisien Regresi Parsial (t test)

2. Uji Koefisien Uji Model (F test)

\section{Hasil dan Pembahasan}

Berdasarkan pengolahan data melalui SPSS 20, didapatkan hasil sebagai berikut:

Tabel 1. Hasil Uji Koefisien Regresi Parsial

\begin{tabular}{|c|c|c|c|c|c|c|c|c|}
\hline \multicolumn{9}{|c|}{ Coefficients $^{a}$} \\
\hline \multirow{2}{*}{\multicolumn{2}{|c|}{ Model }} & \multicolumn{2}{|c|}{ Unstandardized Coefficients } & \multirow{2}{*}{$\begin{array}{c}\text { Standardized } \\
\text { Coefficients } \\
\text { Beta }\end{array}$} & \multirow[b]{2}{*}{$t$} & \multirow[b]{2}{*}{ Sig. } & \multicolumn{2}{|c|}{ Collinearity Statistics } \\
\hline & & $B$ & Std. Error & & & & Tolerance & VIF \\
\hline \multirow[t]{4}{*}{1} & (Constant) & $-60,447$ & 61,914 & &,- 976 & 367 & & \\
\hline & roe & 2,722 & 1,317 & 1,864 & 2,067 &, 084 &, 115 & 8,688 \\
\hline & per & 2,579 & 2,595 &, 508 &, 994 &, 359 &, 358 & 2,790 \\
\hline & ptbv & $-8,940$ & 4,814 & $-1,960$ & $-1,857$ &, 113 &, 084 & 11,896 \\
\hline
\end{tabular}

a. Dependent Variable: return_saham

Apabila $-t_{\text {tabel }} \leq t_{\text {hitung }} \leq t_{\text {tabel }}$, maka $H_{0}$ dapat diterima dan jika $t_{\text {hitung }}>t_{\text {tabel }}$ atau $t_{\text {hitung }}<-t_{\text {tabel }}$, maka $\mathrm{H}_{1}$ diterima atau signifikan. Karena telah menggunakan program SPSS dimana dari tiga variabel bebas (ROE, PER dan PTBV) mempunyai nilai signifikansi diatas 0.05 sehingga ketiga variabel bebas tersebut secara parsial tidak memiliki pengaruh terhadap return saham.

Tabel 2. Hasil Uji Koefisien Uji Model 
ANOVA $^{\mathrm{a}}$

\begin{tabular}{|ll|r|r|r|r|r|}
\hline Model & & $\begin{array}{c}\text { Sum of } \\
\text { Squares }\end{array}$ & df & Mean Square & F & Sig. \\
\hline 1 & Regression & 6821,902 & 3 & 2273,967 & 1,561 & $2^{\text {b }}$ \\
& Residual & 8739,979 & 6 & 1456,663 & & \\
& Total & 15561,882 & 9 & & & \\
\hline
\end{tabular}

a. Dependent Variable: return_saham

b. Predictors: (Constant), ptbv, per, roe

Dengan asumsi bahwa apabila $F_{\text {hitung }} \leq \mathrm{F}_{\text {tabel, }}$ maka $\mathrm{H}_{0}$ dapat diterima dan jika $\mathrm{F}_{\text {hitung }}>\mathrm{F}_{\text {tabel, }}$ maka $\mathrm{H}_{1}$ diterima atau signifikan, atau dapat juga dengan menggunakan nilai probabilitas, apabila nilai Significance F < (alpha), maka hipotesis penelitian $\left(\mathrm{H}_{1}\right)$ dapat diterima.

Pada tabel diatas dengan menggunakan (alpha) sebesar 0.05 terlihat bahwa variabel ROE, PER dan PTBV secara bersama-sama tidak berpengaruh terhadap variabel return saham (Significance $F=0.063>\quad=0.05$ ), ini dapat diartikan bahwa hipotesis yang menyatakan bahwa ROE, PER dan PTBV secara bersama berpengaruh terhadap return saham tidak dapat diterima.

\section{Kesimpulan}

Berdasarkan pembahasan di atas, diketahui bahwa :

1. ROE, PER dan PTBV tidak mempunyai pengaruh terhadap Harga Saham secara parsial.

2. ROE, PER dan PTBV tidak mempunyai pengaruh terhadap Harga Saham secara bersama

Hasil penelitian ini menggambarkan bahwa investor Indonesia cenderung tidak berani mengambil risiko, selama investasi yang investor tanamkan menghasilkan pengembalian yang menurut investor menguntungkan dalam hal ini pendapatan per lembar saham, maka investor akan menanamkan uangnya pada perusahaan tersebut, dengan kata lain para investor tidak memperhitungkan tingkat pengembalian atas investasi yang mereka keluarkan karena mereka lebih mementingkan pendapatan yang konstan dari deviden dibandingkan dengan capital gain.

\section{Referensi}

Yayi Suryo Prabandari, Slide diambilkan dari Reddy (2013) The End-game of Tobacco* * "Tobacco control: The." - Transcript presentasi, Prodi S2 IKM FK UGM, Yogyakarta.

https://m.tempo.co/read/news/2016/01/08/092734426/cukai-rokoksumbangkan-rp-139-5-triliun-selama-2015.

http://www.sahamok.com/emiten/sektor-industri-barang-konsumsi/sub-sektorrokok/ 
Hartono, M. Jogiyanto, 2000. Teori Portofolio dan Analisis Investasi. Yogyakarta: BPFE.

Wijaya, John Henry, 2014, "Penurunan Kinerja Perusahaan Pengaruhnya Terhadap Harga Saham Pada PT. Trikomsel Oke Tbk dan PT. Indofarma Tbk.", Conference on Management and Behavioral Studies Universitas Tarumanagara, Jakarta. 